\title{
PENGARUH SIKAP MENGHINDARI RISIKO SHARING DAN KNOWLEDGE SELF-EFFICACY TERHADAP INFORMAL KNOWLEDGE SHARING PADA MAHASISWA FISE UNY
}

\author{
Oleh : \\ M.Djazari \\ Diana Rahmawati \\ Mahendra Adhi Nugroho
}

Fakultas Ekonomi Universitas Negeri Yogyakarta

\begin{abstract}
ABSTRAK
Penelitian ini bertujuan untuk mengetahui: 1). Pengaruh Sikap Menghidari Risiko Sharing terhadap Informal Knowledge Sharing. 2).Pengaruh Knowledge Self-Efficacy terhadap Informal Knowledge Sharing.

pengaruh sikap menghidari risiko dan tingkat keyakinan individu terhadap kemampuan diri (Knowledge Self-Efficacy) untuk berbagi pengethauan secara informal (Informal Knowledge Sharing) yang terjadi pada mahasiwa Fakultas Ilmu Sosial Dan Ekonomi Universitas Negeri Yogyakarta (FISE UNY). Penelitian ini diharapkan dapat membantu mengetahui pola dan faktor yang menyebabkan penyebaran informasi secara informal yang terjadi pada mahasiswa FISE UNY. Dengan diketahuinya faktor yang mempengaruhi penyebaran informasi secara informal diharapkan dapat membantu penentuan kebijakan cara penyampaian informasi dari Fakultas pada mahasiswa agar efektif dan efisien. Hasil penelitian ini juga diharapkan dapat membantu proses penyebaran pemahaman secara merata mengenai materi kuliah di luar kelas.

Penelitian ini mengunakan metoda survai dengan mengambil sampel mahasiswa FISE UNY yang masih aktif. Sampel diambil secara proposional pada seluruh Program studi yang ada di FISE. Data diolah dengan analisis regresi sederhana dengan alat bantu SPSS 17. Sebelum analisis data, dilaksanakan ujicoba instrumen dengan uji validitas dan uji reliabilitas. Uji prasyarat analisis juga dilakukan untuk memenuhi syarat dilakukannya analisis data model regresi. Uji prasyarat yang dilaksanakan adalah uji normalitas, uji linearitas dan uji asumsi klasik yang terdiri dari uji heteroskedasitas dan uji multikolinearitas.

Hasil dari penelitian menunjukkan bahwa: 1).Terdapat pengaruh negatif signifikan Sikap Menghindari Risiko Sharing terhadap Informal Knowledge Sharing. Hal ini ditunjukkan dengan koefisien regresi bernilai positif $(0,224)$ dengan nilai $p$ value $0,000(p<0,05)$ dengan nilai koefisien determinasi $\mathrm{r}^{2}$ sebesar 0.092. Hasil tersebut menunjukkan bahwa $\mathrm{H} 1$ tidak didukung dalam penelitian ini. 2). Terdapat pengaruh positif signifikan Knowledge Self-Efficacy terhadap Informal Knowledge Sharing. Hal ini ditunjukkan dengan koefisien regresi bernilai positif $(0,229)$ dengan nilai $p$ value $0,000(p<0,05)$ dengan nilai koefisien
\end{abstract}




\section{JURNAL NOMINAL / VOLUME II NOMOR II / TAHUN 2013}

determinasi $\mathrm{r}^{2}$ sebesar 0.103 . Hasil tersebut menunjukkan bahwa $\mathrm{H} 2$ didukung dalam penelitian ini.

Keyword: Informal Knowledge Sharing, Sikap Menghindari Risiko Sharing dan Knowledge Self-Efficacy

\section{A. PENDAHULUAN}

Knowledge sharing didefinisikan sebagai aktivitas mentransfer atau menyebarkan knowledge (termasuk implicit dan tacit knowledge) dari seseorang, grup atau organisasi ke orang, grup atc 1 anisasi yang lain (Lee 2001 dalam Pai 2006). Dalam suatu grup atau organisasi aktivitas knowledge sharing dipengaruhi oleh berbagai faktor. Kwok dan Gao (2004) menggunakan pendekatan motivasi membagi faktor yang mempengaruhi seseorang untuk melakukan knowledge sharing menjadi faktor motivasi intrinsik dan ekstrinsik. Faktor intrinsik mengacu pada motivasi individual yang timbul dari dalam diri sendiri tanpa pengaruh dari faktor luar sedangkan faktor motivasi ekstrinsik terbentuk akibat dari budaya, kebijakan atau konsensus yang dibentuk organisasi atau kelompok. Secara informal, aktivitas knowledge sharing sangat dipengaruhi oleh faktor motivasi intrinsik. Indonesia merupakan negara yang mempunyai kultur masyarakat yang cenderung kolektivis. Masyarakat kolektivis cenderung mempunyai intensitas interaksi secara informal lebih besar daripada intensitas interaksi secara formal. Interaksi tersebut dapat terjadi di dalam maupun di luar organisasi. Fokus dari penelitian ini adalah pengaruh faktor motivasi intrinsik individual terhadap aktivitas knowledge sharing secara informal.

Søndergaard et. al (2008) melakukan review literatur untuk membentuk model knowledge sharing menyimpulkan bahwa aktivitas knowledge sharing dipengaruhi oleh faktor individu, faktor organisasi dan faktor kepemimpinan yang dimediasi oleh kultur sharing. Pengembangan model knowledge sharing juga dikembangkan oleh Lin (2007) yang membagi faktor individu menjadi kesenangan menolong orang lain dan Knowledge Self-Efficacy. Pembagian tersebut merupakan pembagian yang berdasarkan faktor motivasi individu secara intrinsik. Perkembangan pembentukan model knowledge sharing dengan 


\section{JURNAL NOMINAL / VOLUME II NOMOR II / TAHUN 2013}

memasukkan faktor motivasi intrinsik sebagai faktor yang mempengaruhi aktivitas knowledge sharing banyak dilakukan oleh peneliti terdahulu. Hampir seluruh pengembangan tersebut mengacu pada faktor-faktor motivasi intrinsik individual yang berpengaruh positif pada aktivitas knowledge sharing (misal: Wasko dan Faraj 2005; Leung dan Koch, 2006) daripada motivasi untuk menghindari aktivitas knowledge sharing.

Motivasi untuk menghindari knowledge sharing tersebut salah satunya ditunjukkan dengan Sikap Menghindari Risiko Sharing yang dapat diakibatkan oleh persepsi bahwa aktivitas knowledge sharing akan berisiko. Ketakutan sharing mengurangi keamanan kerja seseorang (Riege, 2005). Fenomena anomimitas (tidak mencantumkan nama) pada penyampaian keluhan suatu layanan baik yang dilakukan melalui kotak saran maupun melalui media cetak yang terjadi hampir di seluruh belahan dunia termasuk di Indonesia merupakan contoh fenomena yang menunjukkan adanya sikap untuk menghindari risiko dalam knowledge sharing. Fenomena tersebut didukung oleh penelitian Burnett dan Illingworthz (2008) yang melakukan survei secara online mengenai tanggapan terhadap penataan tempat parkir menunjukkan bahwa 44,8 \% memberikan respon secara anonim. Penelitian ini menggunakan modifikasi dan pengembangan model yang diajukan oleh Søndergaard et. al (2008) dan Lin (2007) dengan dengan dengan mengambil variabel Sikap Menghindari Risiko Sharing dan Knowledge Self-Efficacy sebagai variabel yang mempengaruhi Informal Knowledge Sharing.

\section{B. KAJIAN LITERATUR}

\section{Informal Knwolege Sharing}

Knowledge sharing didefinisikan sebagai aktivitas mentransfer atau menyebarkan knowledge (termasuk implicit dan tacit knowledge) dari seseorang, grup atau organisasi ke orang, grup atau organisasi yang lain (Lee 2001 dalam Pai 2006). Peroses knowledge sharing terjadi tergantung pada lingkukngan terjadinya sharing tersebut. Alavi dan Leidner (2001) memandang bahwa knowledge sharing 


\section{JURNAL NOMINAL / VOLUME II NOMOR II / TAHUN 2013}

sebagai salah suatu proses dari kerangka knowledge management secara keseluruhan sebagai bagian dari knowledge creation, storage, dan application. Dari pendapat tersebut dapat dilihat bahwa knowledge sharing merupakan salah satu aktivitas yang terintegrasi dalam bagian besar dari proses pengelolalan knowledge itu sendiri.

Alavi dan Leidner (2001) mengklasifikasi mekanisme knowledge sharing menjadi empat tipe yaitu: informal vs formal, dan personal vs impersonal. Mekanisme informal termasuk di dalamnya adalah pertemuan yang tidak terjadwal, seminar informal, dan percakapan ketika istirahat. Mekanisme formal dapat berupa pelatihan dan plant tours. Mekanisme personal dapat berupa transfer personel sedangkan mekanisme impersonal dapat berupa komunitas praktik.

Dari beberapa definisi dan pengertian di atas dapat disimpulkan bahwa Informal Knowledge Sharing adalah proses berbagi pengetahuan yang dilakukan dalam lingkungan informal. Lingkungan informal dapat didefinisikan sebagai lingkungan yang tidak terdapat aturan formal yang mengendalikannya.

\section{Sikap Menghindari Risiko Sharing}

Sikap Menghindari Risiko Sharing merupakan reaksi yang diambil seseorang ketika menghadapi lingkungan yang dianggap berisiko. Ketakutan sharing mengurangi keamanan kerja seseorang (Riege, 2005). Informasi atau knowledge power, pada kesamaan dalam status, dan persepsi terhadap kurangnya keamaan kerja dapat juga menjadi penghambat (Riege, 2005). Kedua pernyataan tersebut menunjukkan bahwa jika informasi atau pengetahuan yang akan dibagi dianggap berisiko maka orang akan mempunyai kecenderungan untuk menghindari risiko.

Berbagi pengetahuan sering dianggap sebagai pelemah posisi pegwai dan power dalam perusahaan (Tiwana, 2 5 ). Dalam kontek tersebut, knowledge sharing dianggap dapat meningkatkan risiko seseorang dalam suatu organisasi sehingga meningkatkan risiko sharing. Di lingkungan pegawai sering terjadi kekawatiran ketika melakukan knowledge sharing akan mengurangi keamanan kerja karena ketidak jelasan tujuan dari aktivitas tersebut (Lelic, 2001). Sikap 
tersebut menunjukkan bahwa seseorang akan mencoba menghidari risiko yang diakibatkan oleh aktivitas knowledge sharing.

Dari beberapa pengertian di atas dapat disimpulakan bahwa sikap menhindari risiko merupakan sikap yang diambil seseorang yang mngaggap bahwa aktivitas knowledge sharing dianggap berisiko. Risiko tersebut dapat berupa risiko yang akan berdampak lansung dengan dirinya maupun yang berdampak secara tidak langsung.

\section{Knowledge Self Efficacay}

Untuk melakukan aktivitas berbagi pengetahuan atau informasi seseorang memiliki motivasi tertentu. Motivasi dapat timbul dari faktor intrinsik maupun ektrinsik. Faktor ektrinsik diperoleh seseorang dari lingkungan ketika melakukan knowledge sharing tersebut. Faktror interinsisk diperoleh dari dalam diri seseorang.

Knowledge Self-efficacy merujuk pada kepercayaan diri seseorang untuk berbagi pengetahuan karena kepercayaan terhadap kemapuan diri sendiri terhadap kemapuan atau informasi yang dimiliki. Orang akan lebih tidak suka untuk berkontribusi jika merasa keahlianya tidak sesuai (Wasko dan Faraj, 2002). Dari peryataan tersebut dapat dilhat bahwa orang akan cenderung tidak melakukan aktivitas knowledge sharing jika merasa keahlianya tidak mencukupi.

Anggota suatu komunitas akan lebih memahami aplikasi dari keahlian. Seseorang akan lebih familiar dengan topik diskusi dengan lebih up to date pada isu dikusi inti dana akan cenderung berkontribusi pada pengetahuan baru (Wasko dan Faraj, 2002). Dalam konteks tersebut orang akan melakukan aktivitas knowledge sharing yang dilakukan sesorang jika memiliki kepercayaan terhadap kemampuan diri (Knowledge Self-Efficacy) diri yang tinggi.

Dari beberapa pengertian tersebut dapat disimpulkan bahwa Knowledge Self-Efficacy adalah kepercayaan diri seseorang terhadap kemapuan diri. Kepercayaan diri tersebut merujuk pada kepercayaan diri terhadap pengusaan knowledge atau infromasi yang dimliki. 


\section{JURNAL NOMINAL / VOLUME II NOMOR II / TAHUN 2013}

\section{Model Knowledge sharing Søndergaard et. al}

Søndergaard et. al (2008) melakukan studi kasus penelitian empiris untuk menentukan model knowledge sharing dalam konteks strategis melalui pendekatan sosio-teknikal. Riset yang dilakukan menggunakan faktor hambatan dalam knowledge sharing yang diajukan oleh Riege (2005). Dalam telaah yang dilakukan oleh Riege (2005) mengajukan hambatan-hambatan potensial knowledge sharing yang berasal dari individual, organisasional, dan teknologi. Søndergaard et. all (2008) menerapkan faktor-faktor penghambat tersebut untuk mengembangkan model knowledge sharing dengan melakukan wawancara secara semi terstruktur pada karyawan perusahaan penerbangan multinasional.

Dalam riset yang dilakukan Søndergaard et. al (2008) menemukan tiga faktor utama yang digunakan untuk pemodelan knowledge sharing. Faktor organisasional dan faktor individual merupakan dua faktor yang mempengaruhi kultur knowledge sharing yang akan berdampak pada perilaku knowledge sharing. Interaksi antara kultur knowledge sharing dengan perilaku knowledge sharing dipengaruhi oleh tipe knowledge dan faktor geografis. Kepemimpinan merupakan faktor ketiga yang juga berpengaruh pada kultur knowledge sharing yang berujung pada perilaku knowledge sharing. Pemimpin berperan untuk membentuk kebiasaan knowledge sharing dan membangun jaringan yang mendukung. Model knowledge sharing yang diajukan oleh Søndergaard et. al (2008) disajikan pada gambar 1.

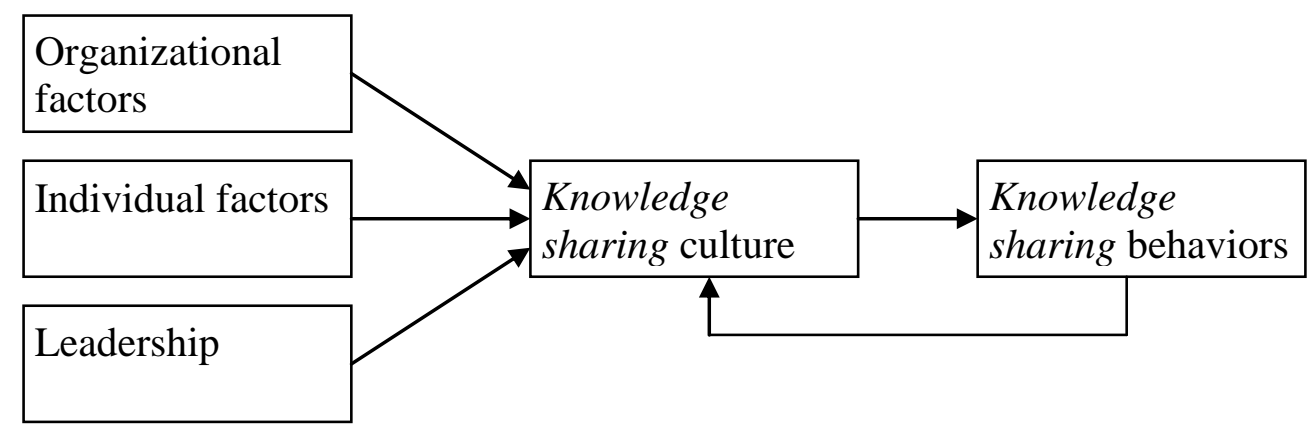

Gambar 1 Model Knowledge sharing Søndergaard et. al (2008) 


\section{JURNAL NOMINAL / VOLUME II NOMOR II / TAHUN 2013}

Di samping tiga faktor tersebut di atas, Søndergaard et. al (2008) juga mendiskusikan faktor yang mempunyai hubungan dua arah yang dapat meningkatkan atau menurunkan perilaku knowledge sharing. Motivasi merupakan faktor pertama yang mempunyai dampak ganda. Motivasi dapat meningkatkan atau menurunkan perilaku knowledge sharing. Faktor kedua adalah trust. Semakin tinggi trust maka akan semakin tinggi pula perilaku knowledge sharing dan semakin rendah trust maka semakin rendah juga perilaku knowledge sharing.

\section{Model Knowledge sharing Lin}

Lin (2007) melakukan riset pembangun model dengan pendekatan proses yang memasukkan dimensi pendukung, dimensi proses sharing dan dimensi outcome. Lin (2007) berargumen bahwa dimensi pendukung proses knowledge sharing terdiri dari faktor individu, faktor organisasi dan faktor teknologi. Faktor individu dibentuk oleh komponen kesenangan menolong orang lain dan Knowledge Self-Efficacy sedangkan faktor organisasional mengacu pada dukungan manajemen puncak dan penghargaan organisasional. Faktor teknologi diindikasikan dengan penggunaan teknologi komunikasi dan informasi. Teknologi komunikasi dan informasi dianggap berperan karena teknologi tersebut dapat mendukung komunikasi dan kolaborasi antar pekerja. Dimensi proses knowledge sharing yang diajukan Lin (2007) mencakup donasi knowledge dan mengumpulkan knowledge. Kedua proses tersebut merupakan komponen utama dalam proses knowledge sharing. Dimensi terakhir yang digunakan Lin (2007) adalah dimensi outcome yang digambarkan dengan kapabilitas perusahaan untuk melakukan inovasi. Model yang diajukan Lin (2007) disajikan pada gambar 2.

Untuk memvalidasi model yang diajukan Lin (2007) melakukan survei pada 50 perusahaan besar di Taiwan. Analisis model persamaan struktural digunakan untuk memvalidasi model. Dari hasil analisa diperoleh bahwa seluruh faktor individual mempunyai pengaruh positif signifikan terhadap proses donasi dan mengumpulkan knowledge, sedangkan faktor organisasional hanya dukungan manajement puncak yang mempunyai pengaruh positif signifikan dan faktor teknologi hanya berpengaruh pada proses mengumpulkan knowledge. 


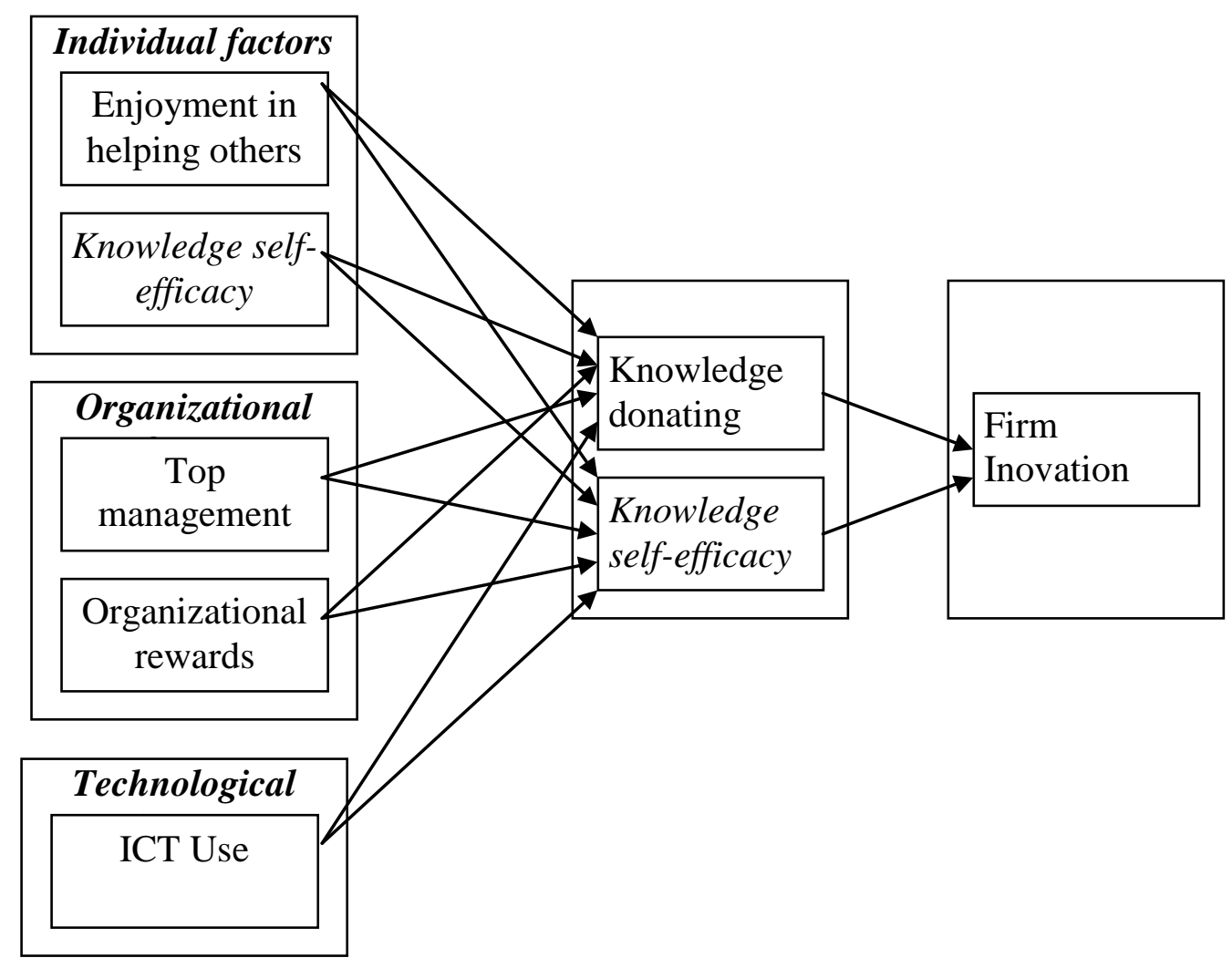

Gambar 2 Model Knowledge sharing Lin (2007)

\section{Pengembangan Hipotesis}

\section{a. Pengaruh Sikap Menghindari Risiko Sharing Terhadap Informal Knowledge Sharing}

Sikap Menghindari Risiko Sharing merupakan suatu sikap sering diambil seseorang jika menghadapi suatu kondisi yang dianggap berisiko. Dalam aktivitas knowledge sharing Sikap Menghindari Risiko Sharing terjadi jika individu tertentu menganggap bahwa sharing yang dilakukan akan berdampak buruk pada dirinya. Riege (2005) mengidentifikasi faktor penghambat knowledge sharing dalam organisasi menyatakan bahwa ketakutan sharing akan mengurangi 'keamanan' kerja akan menjadi penghambat individu untuk melakukan knowledge sharing.

Survai yang dilakukan Burnett dan Illingworthz (2008) pada penataan tempat parkir baru menunjukkan bahwa 44,8 \% responden memberikan respon secara anonim. 95,3\% dari respon anonim tersebut bercerita mengenai pengalaman, isuisu dan kesulitan yang dihadapi. Dari semua pendapat yang masuk 61,3\% 


\section{JURNAL NOMINAL / VOLUME II NOMOR II / TAHUN 2013}

memberikan respon negatif dan 17,2\% memberikan respon sangat negatif, $50 \%$ dari respon negatif tersebut diberikan secara anonim. Survai tersebut menunjukkan bahwa orang akan cenderung mengambil sikap menghindari sharing jika merasa sharing yang dilakukan berisiko. Dengan kata lain, Sikap Menghindari Risiko Sharing akan berpengaruh negatif terhadap knowledge sharing. Dalam konteks informal sikap itu akan semakin kuat jika anonimitas tidak dapat dilakukan. Berdasarkan kajian diatas dapat diajukan hipotesia sebagai berikut:

H1: terdpat pengaruh negatif Sikap Menghindari Risiko Sharing terhadap Informal Knowledge Sharing.

\section{b. Pengaruh Knowledge Self-Efficacy terhadap Informal Knowledge Sharing}

Knowledge sangat terintegrasi dalam karakter personal dan identitas individual. Penilaian diri berdasar pada kompetensi dan penerimaan sosial merupakan sumber penting dari motivasi intrinsik yang memicu ikatan dalam aktivitas untuk menggerakan aktivitas itu sendiri dibanding penghargaan eksternal (Bandura, 1986 dalam Wasko dan Faraj, 2005).

Kepercayaan diri terhadap kemampuan individu dalam suatu bidang (selfefficacy) merupakan salah satu faktor individual yang mempengaruhi kemajuan untuk melakukan knowledge sharing secara informal. Self-efficacy dalam kemampuan untuk knowledge sharing dapat memprediksi perilaku knowledge sharing aktual (Endres, et al. 2007). Knowledge Self-Efficacy mempengaruhi tingkat kepercayaan diri seseorang untuk berbagi dalam suatu bidang tertentu. Orang yang merasa menguasai bidang dalam aktivitas knowledge sharing akan mempunyai kecenderungan untuk lebih aktif. Semakin tinggi Knowledge SelfEfficacy seseorang akan cenderung semakin tinggi aktivitas knowledge sharing yang dilakukan. Self-efficacy seseorang dapat dipicu oleh keahlian diri. Wasko dan Faraj (2005) menemukan hubungan positif antara keahlian diri terhadap kontribusi dalam knowledge sharing. Lu, Leung, dan Koch (2006) menemukan hubungan positif antara self-efficacy dengan knowledge sharing di RRC, 
sedangkan Cho, Li, dan Su (2007) melakukan survei online di Korea menemukan hubungan positif antara self-efficacy dengan minat untuk knowledge sharing. Endres, et al. (2007) melakukan review literatur dan mengajukan proposisi hubungan positif antar self-efficacy dengan knowledge sharing.

Self-efficacy dapat membantu memotivasi pekerja untuk berbagi pengetahuan dengan teman kerja (Wasko and Faraj, 2005). Dalam lingkungan informal tingkat Knowledge Self-Efficacy akan berperan besar dalam knowledge sharing. Orang yang memiliki tingkat self-efficacy tinggi akan cenderung lebih berperan dalam knowledge sharing dibanding dengan orang yang memiliki selfefficacy rendah. Kecenderungan tersebut terjadi karena dalam lingkungan informal tekanan untuk berbagai sangat rendah, orang yang merasa mampu akan mempunyai kecenderungan untuk melakukan knowledge sharing lebih tinggi. Berdasrakan kajian di atas dapat diajukan hipotesis sebagai berikut:

H2: Terdapat pengaruh positif Knowledge Self-Efficacy terhadap Informal Knowledge Sharing.

\section{Model Penelitian}

Berdasarkan hipotesis di atas maka model penelitian atau paradigma penelitian dalam penelitian ini disajikan pada gambar 3 sebagai berikut:

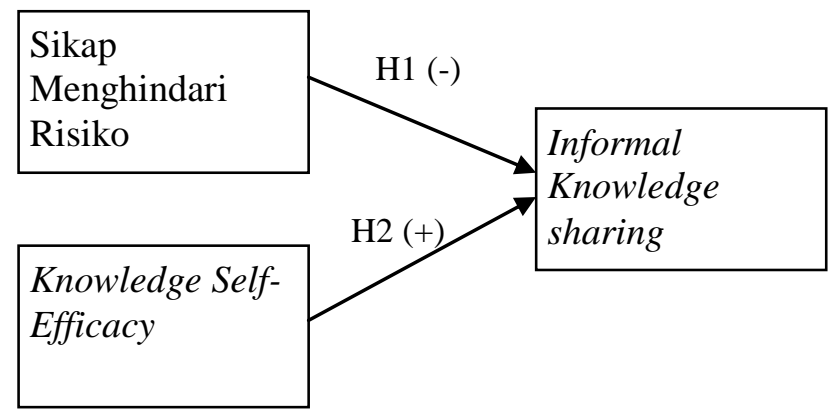

Gambar 3 Model Penelitian 


\section{JURNAL NOMINAL / VOLUME II NOMOR II / TAHUN 2013}

\section{METODE PENELITIAN}

\section{Populasi dan Sampel Penelitian}

Populasi penelitian ini adalah seluruh mahasiswa yang masih aktif di Fakultas Ilmu Sosial Dan Ekonomi Universitas Negeri Yogyakarta. Sampel penelitian menggunakan mahasiswa yang menempuh paling tidak satu mata kuliah yang sama dalam satu semester. Dengan menempuh mata kuliah yang sama diharapkan mahasiswa tersebut mempunyai materi yang sama untuk didiskusikan atau paling tidak saling mengenal satu dengan yang lain sehingga dapat mendukung dalam aktivitas knowledge sharing. Pemilihan mahasiswa sebagai sampel juga didasarkan fakta bahwa mahasiswa tidak mempunyai kewajiban / ikatan utuk melakukan knowledge sharing di luar kelas. Motivasi untuk melakukan knowledge sharing lebih didominasi oleh motivasi individual daripada faktor lain. Sampel diambil dengan metoda survai pada mahasiswa Fakultas Ilmu Sosial Dan Ekonomi Universitas Negeri Yogyakarta. Sampel diambil secara purposive. Fokus survai dilakukan pada aktivitas knowledge sharing di luar kelas mengenai permasalahan yang dihadapi dan bukan knowledge sharing yang dilakukan karena tugas yang diberikan dosen.

Penentuan jumlah sampel minimum ditentukan dengan jumlah variabel latent yang paling komplek dikalikan dengan 10 (Gefen, et al. 2000) dan dengan mengunakan model yang dikembangkan Isaac dan Michael (Sugiyono, 2007). Selain dua metode tersebut penentuan sampel juga dengan melakukan analisis power secara priori. Analisis power priori menggunakan nilai 0.80 dengan alpha 0.5 cukup untuk penelitian bisnis (Hair et al., 1995) menggunakan variabel latent yang paling komplek Analisis power dilakukan menggunakan perangkat lunak $\mathrm{G}^{*}$ Power 3.0.10. Analisis power bertujuan untuk menghindari error statistik tipe 1 dan tipe 2 (Erdfelder, et al. 1996). Ukuran efek (effect size) pada sebagian besar aplikasi paling tidak "small” (Cohen, 1977, 1988 dalam Erdfelder, et al. 1996) untuk memperoleh signifikansi praktis. Ukuran efek mengukur derajat keberadaan fenomena yang sedang diteliti pada populasi (Hair el al., 1995). 


\section{JURNAL NOMINAL / VOLUME II NOMOR II / TAHUN 2013}

\section{Definisi Dan Pengukuran Variabel}

\section{a. Informal Knowledge Sharing}

Informal Knowledge Sharing didefinisikan sebagai proses berbagi dan menerima, ilmu, ide pemikiran antar individu atau kelompok yang dilakukan secara informal dan sukarela. Informal Knowledge Sharing diukur menggunakan perilaku knowledge sharing yang terjadi. Pengukuran knowledge sharing diadopsi dari penelitian Cheng Yeh, dan Tu (2008) dan Lu, Leung, dan Koch (2006) sehingga dalam penelitian ini indikator variabel Informal Knowledge Sharing adalah kenyamanan membagi informasi secara informal. Item pertanyaan dimodifikasi agar sesuai dengan sampel penelitian. Informal Knowledge Sharing diukur menggunakan skala Likert 1-7.

\section{b. Sikap Menghindari Risiko Sharing}

Sikap Menghindari Risiko Sharing didefinisikan sikap yang diambil oleh seseorang yang ditujukan untuk menghindari risiko yang mungkin terjadi sebagai akibat dari aktivitas knowledge sharing yang dilakukan. Sikap Menghindari Risiko Sharing diukur dengan mengembangkan item pertanyaan dalam penelitian Burgess (2005) mengenai knowledge sharing yang berisiko yang terdiri dari keamanan untuk membagi dan kemauan untuk membagi informasi. Skala Likert 1 -7 digunakan untuk mengukur konstruk ini.

\section{c. Knowledge Self-Efficacy}

Knowledge Self-Efficacy didefinisikan sebagai rasa percaya pada kemampuan diri bahwa dirinya menguasai atau memiliki kemampuan yang cukup dalam knowledge tertentu. Knowledge Self-Efficacy diukur dengan mengembangkan item pertanyaan yang digunakan oleh Lin (2007) dan Lu, Leung, dan Koch (2006). Indikator dari variabel Knowledge Self-Efficacy meliputi kepercayaan diri dan keyakinan terhadap penguasaan informasi. Item pertanyaan menggunakan skala Likert 1-7. 


\section{Kisi-Kisi Instrumen}

\begin{tabular}{|l|l|l|}
\hline Varibel & Indikator & No item \\
\hline \multirow{2}{*}{ Knowledge Self-Efficacy } & Kepercayaan diri & $1,2,3,4$ \\
\cline { 2 - 3 } & Keyakinan terhadap penguasaan informasi & $5,6,7,8$ \\
\hline \multirow{2}{*}{ Sikap menghidari risiko } & Keamanan membagi informasi & $9,10,11,12$ \\
\cline { 2 - 3 } & Kemauan untuk membagi informasi & $13,14,15$ \\
\hline $\begin{array}{l}\text { Informal Knowledge } \\
\text { Sharing }\end{array}$ & $\begin{array}{l}\text { Kenyamanan membagi informasi secara } \\
\text { informal }\end{array}$ & $16,17,18,19,20$ \\
\hline
\end{tabular}

\section{Uji Coba Instrumen}

\section{a. Uji Validitas}

Validitas digunakan untuk mengukur sah atau valid tidaknya item-item pertanyaan dalam kuesioner dengan cara menghitung masing-masing butir pertanyaan dengan skor total (Imam gozali, 2009). Uji validitas intrumen menggunakan teknik korelasi antara item pertanyaan masing-masing kontruk dengan skor total. Penentuan valid tidaknya suatu item pertanyan dengan cara membandingkan hasil $r$ hitung dengan $r$ tabel. Jika nilai $r$ hitung lebih besar dari $r$ tabel maka dapat disimpulkan bahwa instrumen tersebut valid. Berikut ini tabel hasil pengujian validitas :

Tabel 1 Hasil uji validitas

\begin{tabular}{|l|l|l|l|}
\hline Variabel & \multicolumn{1}{|c|}{ Indikator/Item Pertanyaan } & Korelasi & Ket. \\
\hline Knowledge Self-Efficacy & Kepercayaan diri 1 & 0,388 & Valid \\
\cline { 2 - 4 } & Kepercayaan diri 2 & 0,366 & Valid \\
\cline { 2 - 4 } & Kepercayaan diri 3 & 0,628 & Valid \\
\cline { 2 - 4 } & Kepercayaan diri 4 & 0,673 & Valid \\
\cline { 2 - 5 } & Keyakinan Penguasaan Informasi 1 & 0,560 & Valid \\
\cline { 2 - 5 } & Keyakinan Penguasaan Informasi 2 & 0,634 & Valid \\
\cline { 2 - 5 } & Keyakinan Penguasaan Informasi 3 & 0,511 & Valid \\
\cline { 2 - 5 } & Keyakinan Penguasaan Informasi 4 & 0,644 & Valid \\
\hline Sikap Menghidari Risiko & Keamanan membagi informasi 1 & 0,482 & Valid \\
\cline { 2 - 4 } & Keamanan membagi informasi 2 & 0,331 & Valid \\
\cline { 2 - 4 } & Keamanan membagi informasi 3 & 0,667 & Valid \\
\hline
\end{tabular}


JURNAL NOMINAL / VOLUME II NOMOR II / TAHUN 2013

\begin{tabular}{|c|c|c|c|}
\hline Variabel & Indikator/Item Pertanyaan & Korelasi & Ket. \\
\hline & Keamanan membagi informasi 4 & 0,662 & Valid \\
\hline & Kemauan untuk membagi 1 & 0,769 & Valid \\
\hline & Kemauan untuk membagi 2 & 0,742 & Valid \\
\hline & Kemauan untuk membagi 3 & 0,556 & Valid \\
\hline \multirow[t]{5}{*}{$\begin{array}{l}\text { Informal } \\
\text { Sharing }\end{array}$} & $\begin{array}{l}\text { Kenyamanan membagi informasi secara } \\
\text { informal } 1\end{array}$ & 0,612 & Valid \\
\hline & $\begin{array}{l}\text { Kenyamanan membagi } \text { informasi secara } \\
\text { informal } 2\end{array}$ & 0,414 & Valid \\
\hline & $\begin{array}{l}\text { Kenyamanan membagi informasi secara } \\
\text { informal } 3\end{array}$ & 0,473 & Valid \\
\hline & $\begin{array}{l}\text { Kenyamanan membagi informasi secara } \\
\text { informal } 4\end{array}$ & 0,717 & Valid \\
\hline & $\begin{array}{l}\text { Kenyamanan membagi informasi secara } \\
\text { informal } 5\end{array}$ & 0,543 & Valid \\
\hline
\end{tabular}

Sumber: Data yang diolah

Berdasarkan tabel diatas diperoleh hasil bahwa nilai kolerasi ( $\mathrm{r}$ hitung) seluruh item pertanyaan tiap-tiap variabel penelitian lebih besar dibandingkan dengan $r$ tabel sehingga seluruh item pertanyaan pada masing-masing variabel yang diteliti dikatakan valid.

\section{c. Uji Reliabilitas}

Reliabilitas adalah alat untuk mengukur apakah suatu item pertanyaan kuisoner merupakan indikator dari suatu variabel atau konstruk (Imam Gozali, 2009). Reliabilitas intrumen diukur menggunakan nilai cronbach's alpha. Reliabilitas dilihat dari hasil nilai Cronbach's alpha minimal 0,7 (Hair et al., 1995). Berikut dibawah ini tabel hasil uji reliabilitas :

Tabel 2 Hasil uji relaibilitas

\begin{tabular}{|l|l|l|}
\hline Variabel & Nilai Cronbac's Alpha & Keterangan \\
\hline Knowledge Self-Efficacy & 0,816 & Reliabel \\
\hline Sikap Menghidari Risiko & 0,836 & Reliabel \\
\hline Informal Knowledge Sharing & 0,775 & Reliabel \\
\hline
\end{tabular}

Sumber : Data yang diolah 
Berdasarkan tabel diatas, diperoleh hasil bahwa nilai cronbach'alpha masingmasing veriabel yang diteliti lebih besar dari 0,7 yang berarti seluruh variabel penelitian adalah reliabel. Sehingga item pertanyaan kuesioner merupakan indikator dari variabel-variabel yang diteliti.

\section{d. Uji prasyarat}

Sebelum dilakukan pengujian hipotesis pada setiap persamaan, dilakukan uji prasyarat analisis yang meliputi:

\section{1). Normalitas}

Uji Normalitas digunakan untuk menguji distribusi sebaran data dari variabel penelitian yang diteliti.Uji normalitas dilakukan dengan menggunakan uji skweness. Jika nilai skwewness berada diantara -1 dan +1 maka data dapat dikatakan normal (Leech, et al, 2005)

\section{2). Linearitas.}

Uji linearitas di gunakan untuk memilih model regresi yang akan digunakan. Uji linearitas dimaksudkan untuk mengetahui ada tidaknya hubungan secara linear antara variabel dependen terhadap setiap variabel independen yang hendak diuji. Jika suatu model tidak memenuhi syarat linearitas maka model regresi linear tidak bisa digunakan. Untuk menguji linearitas suatu model dapat digunkan uji linearitas dengan melakukan regresi terhadap model yang ingin diuji. Aturan untuk keputusan linearitas dapat dengan membandingkan nilai signifikansi dari deviation from linearity yagn dihasilkan dari uji linearitas (menggunakan bantuan SPSS) dengan nilai alpha yang digunakan. Jika nilai signifikansi dari Deviation from Linearity > alpha $(0,05)$ maka nilai tersebut linear (R. gunawan Sudarmanto, 2005).

\section{e. Uji Asumsi Klasik}

\section{1). Heteroskedasitas}

Untuk mendeteksi ada tidaknya heteroskedasitas digunakan rank korelasi dari Spearman (Gujarati, 1997 dalam R.Gunawan, 2005). Kriteria yang digunakan 
untuk menyatakan apakah terjadi heteroskedasitas digunakan perbandingan antara nilai alpha yang ditentukan dengan tingkat signifikansi dari hasil olahan data. Dengan menggunakan alpha $5 \%$ maka dapat ditarik kesimpulan jika koefisien signifikansi $<0.05$ maka terjadi heteroskedasitas dan sebaliknya, jika koefisiean signifikansi > 0.05 maka tidak terjadi heteroskedasitas

\section{2). Multikolinearitas.}

Pengujian ini dimaksudkan untuk mengetahui apakah pada model regresi ditemukan adanya korelasi antar variabel independen. Jika terjadi korelasi, maka dinamakan terdapat masalah multikolinearitas dan model regresi yang baik seharusnya tidak terjadi korelasi antar variabel dependen (Singgih, 2000). Variabel-variabel regresor (independen) tidak memiliki masalah multikolinearitas jika nilai VIF-nya dan nilai tolerance-nya sama dengan satu, namun sebagai rule of thumb, VIF akan menjadi masalah jika memiliki nilai melebihi 10 (Gujarati, 1995).

\section{Uji hipotesis}

Untuk menguji seluruh hipotesis yang diajukan (hipotesis 1 dan 2) digunakan analisis regresi sederhana. Analisis regresi sederhana yang digunakan pada penelian ini mempunyai persamaan sebagai berikut:

$Y=a+b X$

Keterangan:

$\mathrm{Y}=$ Variabel dependen yang diprediksi (Informal Knowledge Sharing)

$\mathrm{a}=$ nilai konstanta

$\mathrm{b}=$ koefisien regresi

$\mathrm{X}=$ subyek variabel independen (Knowledge Self-Efficacy / sikap menghidari risiko)

Pengujian hipotesis menggunakan alat bantu program SPSS 17. Pengujian dilakukan sekali pada setiap hipotesis yang diajukan. Pengambilan keputusan pada uji hipotesis dengan melihat nilai signifikansi pada hasil uji t yang disajikan oleh program SPSS 17. Hipotesis di terima jika nilai signifikansi > 0,05 (df: 5\%). 
Untuk mengetahui kemampuan setiap varibel $\mathrm{X}$ dalam mempengaruhi variable $\mathrm{Y}$ dilihat dari nilai koefisien determinasi $\left(\mathrm{r}^{2}\right)$. Nilai $\mathrm{r}^{2}$ akan berada pada rentang 0 sampai 1, semakin besar nilai $\mathrm{r}^{2}$ semakin besar kemampuan variabel independen (X) mempengaruhi variabel dependen (Y) dalam model yang diajukan.

\section{HASIL PENELITIAN}

\section{Deskripsi Statistik Responden}

Setelah dilaksanakan penyebaran kuesioner terkumpul jumlah responden sebesar 434 responden. Adapun perincian distribusi responden disajikan dalam tabel sebagai berikut:

Tabel 3 Distribusi Responden

\begin{tabular}{|c|c|c|}
\hline \multicolumn{3}{|c|}{ Panel A: Berdasar Jenis Kelamin } \\
\hline Jenis Kelamin & Jumlah & $\%$ \\
\hline Laki-Laki & 147 & $33,9 \%$ \\
\hline Perempuan & 270 & $62,2 \%$ \\
\hline Tidak Memberi Keterangan & 17 & $3,9 \%$ \\
\hline Jumlah & 434 & $100 \%$ \\
\hline \multicolumn{3}{|l|}{ Panel B: Berdasar Angkatan } \\
\hline Angkatan & Jumlah & $\%$ \\
\hline 2007 & 90 & $20,7 \%$ \\
\hline 2008 & 93 & $21,4 \%$ \\
\hline 2009 & 123 & $28,3 \%$ \\
\hline 2010 & 115 & $26,5 \%$ \\
\hline Tidak Memberi Keterangan & 13 & $3,0 \%$ \\
\hline Jumlah & 434 & $100 \%$ \\
\hline \multicolumn{3}{|c|}{ Panel C: Berdasar Program Studi } \\
\hline Prodi & Jumlah & $\%$ \\
\hline Akuntansi & 46 & $10,6 \%$ \\
\hline Manajemen & 45 & $10,4 \%$ \\
\hline Sosiologi & 35 & $8,1 \%$ \\
\hline P. Akuntansi & 44 & $10,2 \%$ \\
\hline P. Sejarah & 33 & $7,6 \%$ \\
\hline P. Ekonomi & 44 & $10,1 \%$ \\
\hline ADP & 40 & $9,2 \%$ \\
\hline P. Geografi & 40 & $9,2 \%$ \\
\hline PKNH & 36 & $8,3 \%$ \\
\hline Ilmu Sejarah & 9 & $2,1 \%$ \\
\hline Adminritrasi Negara & 24 & $5,5 \%$ \\
\hline P. IPS & 25 & $5,8 \%$ \\
\hline Tidak Memberi Keterangan & 13 & $3,0 \%$ \\
\hline Jumlah & 434 & $100 \%$ \\
\hline
\end{tabular}

Sumber : data primer yang diolah 
Berdasarkan tabel di atas, distribusi responden berdasarkan jenis kelamin diketahui bahwa jumlah responden wanita (270 responden) lebih besar dibandingkan dengan jumlah responden laki-laki (147 responden). Dalam penelitian ini juga diketahui bahwa jumlah mahasiswa angkatan 2009 (123 mahasiswa) paling besar dibandingkan mahasiswa angkatan 2007 (90 mahasiswa), angkatan 2008 (93 mahasiswa), angkatan 2010 (115 mahasiswa). Distribusi responden berdasarkan Program Studi diketahui bahwa jumlah responden dari Program Studi A 18 ınsi (46 responden) paling besar dibandingkan dengan Program Studi-program studi yang lain. Jumlah responden dari Program Studi Ilmu Sejarah paling rendah (9 responden) dibandingkan dengan Program Studi lainnya. Hasil statisik deskriptif variabel penelitian ini ditunjukkan dalam tabel dibawah ini

Tabel 4 Statistik deskriptif

\begin{tabular}{|l|r|r|r|}
\hline & X2_KSA & X1_SMR & \multicolumn{1}{|c|}{ Y_IKS } \\
\hline N Valid & 434 & 434 & 434 \\
Missing & 0 & 0 & 0 \\
Mean & 20.4839 & 21.0576 & 13.9839 \\
Std. Error of Mean & .35224 & .34167 & .25188 \\
Median & 20.0000 & 20.0000 & 14.0000 \\
Mode & 16.00 & 14.00 & 17.00 \\
Std. Deviation & 7.33815 & 7.11787 & 5.24743 \\
Variance & 53.848 & 50.664 & 27.536 \\
Skewness & .608 & .376 & .339 \\
Std. Error of Skewness & .117 & .117 & .117 \\
Kurtosis & .010 & -.569 & -.457 \\
Std. Error of Kurtosis & .234 & .234 & .234 \\
Range & 34.00 & 32.00 & 25.00 \\
Minimum & 8.00 & 7.00 & 5.00 \\
Maximum & 42.00 & 39.00 & 30.00 \\
Sum & 8890.00 & 9139.00 & 6069.00 \\
\hline
\end{tabular}


Tabel statistik deskriptif menunjukkan distibusi data dan penjabaran data secara deskriptif dari setiap variable penalitian. Dari data yang telah diolah menunjukkan bahwa skor minimum dari varibel Infromal Knowledge Sharing, Sikap Menghindari Risiko Sharing, dan Knowledge Self-Efficacy secara berturutturut adalah 5,7, dan 8 sedangkan nilai maksimumnya adalah 30, 39, dan 42 dengan range 25,32,dan 34. Darai data tersebut dapat dilihat bahwa rentang data dari setiap variabel mempunyai jarak dan rentang cukup luas, dengan demikian dapat dilihat bahwa data terdistribusi dengan cukup merata. Kencenderungan data dari setiap variabel dapat dilihat dari nilai skwenes masing-masing variabel. Semua variabel memiliki nilai skwenes yang bernilai positif dan mempunyai nilai kurang dari $1(0,339 ; 0,376$ dan 0,608). Dari nilai skwenes yang diperoleh dapat ditarik kesimpulan bahwa semua variabel mempunyai kecenderungan ke kanan (right skwed), dengan kata lain responden mempunyai kecenderungan menjawab pada skor yang rendah pada item pertanyaan kuisioner setiap variabel penelitian. Meskipun demikian, kecenderungan tersebut tidak terjadi pada setiap responden yang ditunjukkan dengan nilai Mean dan Modus setiap variabel. Variabel Informal Knowledge Sharing memiliki Mean 13,98 dengan Modus 17,00 dari data tersebut dapat dilihat bahwa data menunjukkan skor di atas nilai tengah distribusi data $($ Median $=14,00)$ sedangkan nilai skwenes menunjukkan kecenderungan ke kanan. Variabel Sikap Menghindari Risiko Sharing memiliki skor Mean 21,05 dan Modus 14,00 menunjukkan bahwa data menunjukkan skor di bawah nilai tengah (Median $=20,00)$ sedangkan skwenes menujukkan kecederungan ke kanan. Variabel terakhir dari penelitian ini adalah Knowledge Self-Efficacy, nilai Mean variabel tersebut adalah 20,48 dengan Modus 16,00, nilai Mean mempunyai nilai lebih tinggi dari nilai tengah sedangkan nilai Modus mepunyai nilai lebih rendah dari nilai tengah (Median $=20,00$ ). Dari nilai tersebut memperkuat simpulan bahwa responden menunjukkan kecenderungan menjawab pada skor rendah meskipun kecenderungan tersebut hanya tipis (skewnes berada pada nilai 0 $-1)$. 


\section{Hasil Uji Prasyarat Analisis}

a. Uji Normalitas

Uji Normalitas digunakan untuk menguji distribusi sebaran data dari variabel penelitian yang diteliti.Uji normalitas dilakukan dengan menggunakan uji skweness. Adapun hasil uji normalitas adalah sebagai berikut :

\section{Tabel 5 Uji Normalitas}

\begin{tabular}{|c|c|c|c|}
\hline & \multirow{2}{*}{$\begin{array}{l}\mathrm{N} \\
\text { Statistic }\end{array}$} & \multicolumn{2}{|c|}{ Skewness } \\
\hline & & Statistic & Std. Error \\
\hline $\mathrm{X} 2 \_\mathrm{KSA}$ & 434 & .608 & .117 \\
\hline X1_SMR & 434 & .376 & .117 \\
\hline Y_IKS & 434 & .339 & .117 \\
\hline Valid N (listwise) & 434 & & \\
\hline
\end{tabular}

Berdasarkan tabel di atas menunjukkan bahwa data dari masing-masing variabel yang diteliti terdistribusi secara normal. Hal ini ditunjukkan dengan nilai statistics skewness dari semua variabel yang diteliti berada diantara -1 dan +1 yang berarti bahwa data terdistribusi secara normal sehingga uji hipotesis dapat dilanjutkan.

\section{b. Uji Linearitas}

Uji linearitas digunakan untuk memilih model regresi yang akan digunakan. Uji linearitas dimaksudkan untuk mengetahui ada tidaknya hubungan secara linear antara variabel dependen terhadap setiap variabel independen yang hendak diuji. Aturan untuk keputusan linearitas didapat dengan membandingkan nilai signifikansi dari deviation from linearity yang dihasilkan dari uji linearitas (menggunakan bantuan SPSS) dengan nilai alpha yang digunakan. Jika nilai signifikansi dari Deviation from Linearity > alpha $(0,05)$ maka nilai tersebut linear. Hasil uji linearitas ditunjukkan dalam tabel sebagai berikut : 
JURNAL NOMINAL / VOLUME II NOMOR II / TAHUN 2013

Tabel 6 Hasil Uji Linearitas

\begin{tabular}{|c|c|c|c|c|c|c|c|}
\hline & & & $\begin{array}{l}\text { Sum of } \\
\text { Squares }\end{array}$ & $d f$ & $\begin{array}{l}\text { Mean } \\
\text { Square }\end{array}$ & $\mathrm{F}$ & Sig. \\
\hline \multirow{5}{*}{$\begin{array}{l}\text { Y_IKS * } \\
\text { X2_KSA }\end{array}$} & \multirow{3}{*}{$\begin{array}{l}\text { Between } \\
\text { Groups }\end{array}$} & (Combined) & 2049.137 & 33 & 62.095 & 2.516 & .000 \\
\hline & & Linearity & 1223.163 & 1 & 1223.163 & 49.552 & .000 \\
\hline & & $\begin{array}{l}\text { Deviation } \\
\text { from } \\
\text { Linearity }\end{array}$ & 825.974 & 32 & 25.812 & 1.046 & .403 \\
\hline & $\begin{array}{l}\text { Within } \\
\text { Groups }\end{array}$ & 9873.750 & 400 & 24.684 & & & \\
\hline & Total & 11922.887 & 433 & & & & \\
\hline \multirow{5}{*}{$\begin{array}{l}\text { Y_IKS * } \\
\text { X1_SMR }\end{array}$} & \multirow{3}{*}{$\begin{array}{l}\text { Between } \\
\text { Groups }\end{array}$} & (Combined) & 1835.017 & 32 & 57.344 & 2.279 & .000 \\
\hline & & Linearity & 1098.227 & 1 & 1098.227 & 43.655 & .000 \\
\hline & & $\begin{array}{l}\text { Deviation } \\
\text { from } \\
\text { Linearity }\end{array}$ & 736.790 & 31 & 23.767 & .945 & .555 \\
\hline & $\begin{array}{l}\text { Within } \\
\text { Groups }\end{array}$ & 10087.870 & 401 & 25.157 & & & \\
\hline & Total & 11922.887 & 433 & & & & \\
\hline
\end{tabular}

Berdasarkan tabel di atas, nilai signifikansi devitiation of linearity dari hubungan variabel $\mathrm{X}_{1}$ dan $\mathrm{X}_{2}$ terhadap $\mathrm{Y}>0,05$ yang bearti bahwa hubungan kedua variabel independen tersebut dengan variabel dependen adalah linier.

\section{Uji Asumsi Klasik}

\section{a. Uji Heteroskedasitas}

Untuk mendeteksi ada tidaknya heteroskedasitas digunakan rank korelasi dari Spearman (Gujarati, 1997 dalam R.Gunawan, 2005). Kriteria yang digunakan dengan menggunakan alpha $5 \%$, jika koefisien signifikansi $<0.05$ maka terjadi heteroskedasitas dan sebaliknya, jika koefisiean signifikansi > 0.05 maka tidak terjadi heteroskedasitas. Hasil uji heteroskedasitas ditunjukkan dalam tabel sebagai berikut : 
Tabel 7 Hasil uji Heteroskedasitas

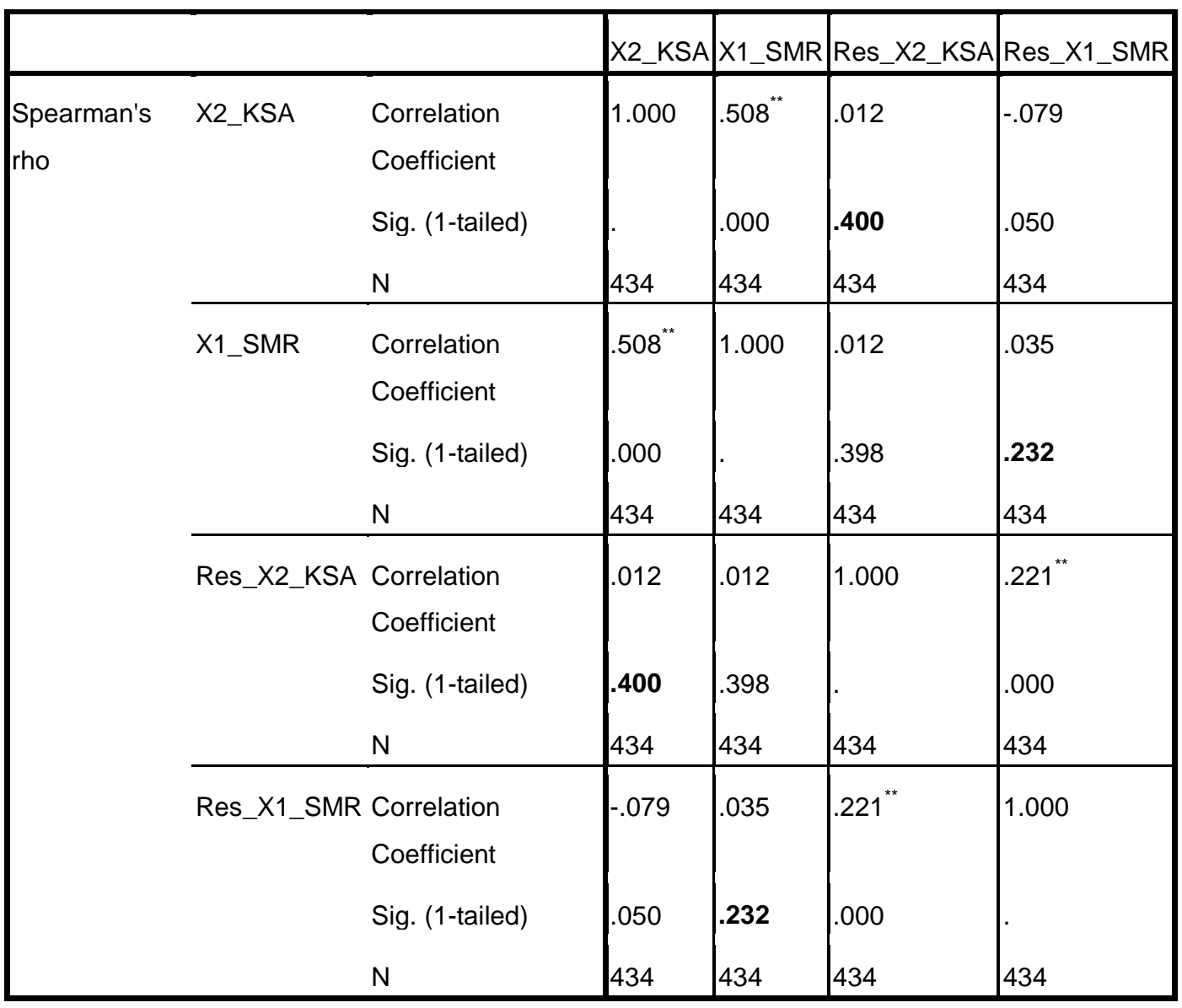

${ }^{* *}$. Correlation is significant at the 0.01 level (1-tailed).

Berdasarkan data di atas diperoleh nilai korelasi varibel $\mathrm{X}_{1}$ dengan residual Variabel $\mathrm{X}_{2}$ dan nilai korelasi variable $\mathrm{X}_{2}$ dengan residual varibel $\mathrm{X}_{2}$ seluruhnya > 0,05. Hal ini berarti bahwa tidak terjadi / tidak ada gejala heteroskedasitas sehingga pengujian model regresi dapat dilanjutkan.

\section{b. Multikolinearitas}

Pengujian ini dimaksudkan untuk mengetahui apakah pada model regresi ditemukan adanya korelasi antar variabel independen. Variabel-variabel independen tidak memiliki masalah multikolinearitas jika nilai VIF-nya dan nilai tolerance-nya tidak lebih dari 10. Berikut hasil uji multikolinearitas : 
Tabel 8 Hasil Uji Multikolinearitas

\begin{tabular}{|c|c|c|c|c|c|c|c|c|c|c|}
\hline \multirow[b]{2}{*}{ Model } & \multicolumn{2}{|c|}{$\begin{array}{l}\text { Unstandardized } \\
\text { Coefficients }\end{array}$} & \multirow{2}{*}{$\begin{array}{l}\text { Standardized } \\
\text { Coefficients } \\
\text { Beta }\end{array}$} & \multirow[b]{2}{*}{$\mathrm{t}$} & \multirow[b]{2}{*}{ Sig. } & \multicolumn{3}{|c|}{ Correlations } & \multicolumn{2}{|l|}{$\begin{array}{l}\text { Collinearity } \\
\text { Statistics }\end{array}$} \\
\hline & $B$ & Std. Error & & & & order & Partial & Part & Tolerance & VIF \\
\hline 1 (Constant) & 7.729 & .818 & & 9.448 & .000 & & & & & \\
\hline X2_KSA & .161 & .037 & .225 & 4.327 & .000 & .320 & .204 & .194 & .749 & 1.335 \\
\hline X1_SMR & .141 & .038 & .191 & 3.679 & .000 & .303 & .174 & .165 & .749 & 1.335 \\
\hline
\end{tabular}

a. Dependent Variable: Y_IKS

Hasil uji multikolinearitas menunjukkan bahwa nilai VIF pada kedua variabel independen tidak lebih dari 10 yang berarti bebas dari gejala multikolinearitas. Hal ini menunjukkan bahwa uji model regresi dapat dilanjutkan.

\section{Hasil Uji Hipotesis}

\section{a. Hipotesis Pertama}

Terdapat pengaruh negatif Sikap Menghindari Risiko Sharing terhadap Informal Knowledge Sharing.

Hipotesis pertama diuji dengan menggunakan uji regresi sederhana. Hasil uji regresi sederhana pada tabel di bawah ini :

Tabel 9 Model Summary H1

\begin{tabular}{|c|c|c|c|c|c|c|c|c|c|c|}
\hline \multirow[b]{2}{*}{ Model } & \multirow[b]{2}{*}{$\mathrm{R}$} & \multirow[b]{2}{*}{$\begin{array}{l}\mathrm{R} \\
\text { Square }\end{array}$} & \multirow[b]{2}{*}{$\begin{array}{l}\text { Adjusted } \\
\text { R Square }\end{array}$} & \multirow{2}{*}{$\begin{array}{l}\text { Std. Error } \\
\text { of the } \\
\text { Estimate }\end{array}$} & \multicolumn{5}{|c|}{ Change Statistics } & \multirow[b]{2}{*}{$\begin{array}{l}\text { Durbin- } \\
\text { Watson }\end{array}$} \\
\hline & & & & & $\begin{array}{l}R \text { Square } \\
\text { Change }\end{array}$ & $\begin{array}{l}F \\
\text { Change }\end{array}$ & df1 & df2 & $\begin{array}{l}\text { Sig. F } \\
\text { Change }\end{array}$ & \\
\hline 1 & $.303^{\mathrm{a}}$ & .092 & .090 & 5.00571 & .092 & 43.829 & 1 & 432 & .000 & 1.954 \\
\hline
\end{tabular}
a. Predictors: (Constant), X1_SMR
b. Dependent Variable: Y_IKS 
Coefficients $^{\mathrm{a}}$

\begin{tabular}{|c|c|c|c|c|c|c|c|c|c|c|}
\hline \multirow[b]{2}{*}{ Model } & \multicolumn{2}{|c|}{$\begin{array}{l}\text { Unstandardized } \\
\text { Coefficients }\end{array}$} & \multirow{2}{*}{  } & \multirow[b]{2}{*}{$\mathrm{t}$} & \multirow[b]{2}{*}{ Sig. } & \multicolumn{3}{|c|}{ Correlations } & \multicolumn{2}{|l|}{$\begin{array}{l}\text { Collinearity } \\
\text { Statistics }\end{array}$} \\
\hline & $B$ & $\begin{array}{l}\text { Std. } \\
\text { Error }\end{array}$ & & & & $\begin{array}{l}\text { Zero- } \\
\text { order }\end{array}$ & Partial & Part & Tolerance & VIF \\
\hline $\begin{array}{c}1 \text { (Constant) } \\
\text { X1_SMR }\end{array}$ & $\begin{array}{l}9.272 \\
.224\end{array}$ & $\begin{array}{l}.751 \\
.034\end{array}$ & .303 & $\begin{array}{l}12.344 \\
6.620\end{array}$ & $\begin{array}{l}.000 \\
.000\end{array}$ & .303 & .303 & .303 & 1.000 & 1.000 \\
\hline
\end{tabular}

a. Dependent Variable: Y_IKS

Berdasarkan tabel diatas, maka persamaan garis regresi dapat dinyatakan sebagai berikut:

$$
\mathrm{Y}=9,272+0,224 \mathrm{X}_{1}+\mathrm{e}
$$

Persamaan menunjukkan bahwa nilai koefisien bernilai positif ( 0,224$)$ dengan nilai $p$-value $=0,000(p<0,05)$ yang berarti signifikan. Hal ini berarti bahwa Sikap Menghindari Risiko Sharing berpengaruh positif dan signifikan dengan Informal Knowledge Sharing dengan harga koefisien determinasi $\mathrm{r}^{2}$ sebesar 0.092 hal ini berarti $\mathrm{H} 1$ tidak didukung oleh data dalam penelitian ini. Hasil analisis menunjukkan bahwa responden cenderung tidak memperdulikan risiko ketika melakukan knowledge sharing.

\section{b. Hipotesis Kedua}

Terdapat pengaruh positif Knowledge Self-Efficacy terhadap Informal Knowledge Sharing.

Hipotesis kedua diuji dengan menggunakan uji regresi sederhana. Hasil uji regresi sederhana pada tabel dibawah ini :

Tabel 10 Model Summary H2

\begin{tabular}{|c|c|c|c|c|c|c|c|c|c|c|}
\hline \multirow[b]{2}{*}{ Model } & \multirow[b]{2}{*}{$\mathrm{R}$} & \multirow[b]{2}{*}{$\begin{array}{l}\mathrm{R} \\
\text { Square }\end{array}$} & \multirow[b]{2}{*}{$\begin{array}{l}\text { Adjusted R } \\
\text { Square }\end{array}$} & \multirow[b]{2}{*}{$\begin{array}{l}\text { Std. Error of } \\
\text { the Estimate }\end{array}$} & \multicolumn{5}{|c|}{ Change Statistics } & \multirow[b]{2}{*}{$\begin{array}{l}\text { Durbin- } \\
\text { Watson }\end{array}$} \\
\hline & & & & & $\left|\begin{array}{l}R \\
\text { Change }\end{array}\right|$ & $\mid \begin{array}{l}\text { F } \\
\text { Change }\end{array}$ & df1 & df2 & $\begin{array}{l}\text { Sig. F } \\
\text { Change }\end{array}$ & \\
\hline 1 & $.320^{\mathrm{a}}$ & .103 & .101 & 4.97673 & .103 & 49.385 & 1 & 432 & .000 & 1.932 \\
\hline
\end{tabular}

a. Predictors: (Constant), X2_KSA

b. Dependent Variable: Y_IKS 
Coefficients $^{\mathrm{a}}$

\begin{tabular}{|c|c|c|c|c|c|c|c|c|c|c|}
\hline \multirow[b]{2}{*}{ Model } & \multicolumn{2}{|c|}{$\begin{array}{l}\text { Unstandardized } \\
\text { Coefficients }\end{array}$} & \multirow{2}{*}{ 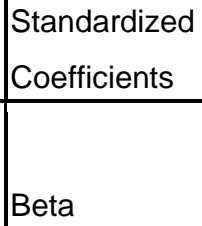 } & \multirow[b]{2}{*}{$\mathrm{t}$} & \multirow[b]{2}{*}{ Sig. } & \multicolumn{3}{|c|}{ Correlations } & \multicolumn{2}{|c|}{$\begin{array}{l}\text { Collinearity } \\
\text { Statistics }\end{array}$} \\
\hline & $B$ & $\begin{array}{l}\text { Std. } \\
\text { Error }\end{array}$ & & & & $\begin{array}{l}\text { Zero- } \\
\text { order }\end{array}$ & Partial & Part & Tolerance & VIF \\
\hline 1 (Constant) & 9.292 & .709 & & 13.105 & .000 & & & & & \\
\hline X2_KSA & .229 & .033 & .320 & 7.027 & .000 & .320 & .320 & .320 & 1.000 & 1.000 \\
\hline
\end{tabular}

Dependent Variable: Y_IKS

Berdasarkan tabel di atas, maka persamaan garis regresi dapat dinyatakan sebagai berikut:

$$
\mathrm{Y}=9,292+0,229 \mathrm{X}_{2}+\mathrm{e}
$$

Persamaan menunjukkan bahwa nilai koefisien bernilai positif $(0,229)$ nilai $p$ value $=0,000(p<0,05)$ hal ini berarti bahwa Knowledge Self-Efficacy berpengaruh positif dan signifikan dengan Informal Knowledge Sharing dengan koefisien determinasi $\mathrm{r}^{2}$ sebesar 0.103 hal ini berarti $\mathrm{H} 2$ didukung oleh data dalam penelitian ini.

\section{Pembahasan}

\section{a. Pengaruh Sikap Menghindari Risiko Sharing Dengan Informal Knowledge Sharing}

Hasil penelitian ini menunjukkan bahwa Sikap Menghindari Risiko Sharing berpengaruh positif dan signifikan terhadap Informal Knowledge Sharing. Pengaruh positif bermakna bahwa semakin tinggi Sikap Menghindari Risiko Sharing yang di lakukan oleh mahasiswa maka justru semakin tinggi pula keinginan mahasiswa untuk melakukan sharing pengetahuan secara informal.

Hasil penelitian ini tidak mendukung hipotesis pertama yang menyatakan bahwa Sikap Menghindari Risiko Sharing berpengaruh negative terhadap Informal Knowledge Sharing. Pengaruh negatif berarti semakin tinggi Sikap Menghindari Risiko Sharing yang dilakukan mahasiswa maka akan semakin rendah keinginan mahasiswa untuk berbagi pengetahuan secara informal. Hasil analisis tersebut diatas bermakna bahwa mahasiswa mengabaikan risiko ketika berbagi pengetahuan secara informal. Hal ini sesuai dengan karakteristik dan jiwa 


\section{JURNAL NOMINAL / VOLUME II NOMOR II / TAHUN 2013}

muda mahasiswa yang senang berbagi pengetahuan, bertindak dan suka mencoba hal baru tetapi kurang mempertimbangkan risiko yang akan dihadapi.

Implikasi teoritis dari penelitian ini adalah untuk mengetahui pengaruh Sikap Menghindari Risiko Sharing terhadap Informal Knowledge Sharing harus memperhatikan dan mempertimbangkan karakteristik responden yang akan menjadi subyek penelitian. Karakteristik responden terbukti berpengaruh terhadap hasil penelitian. Implikasi secara praktis dari penelitian ini adalah fakultas hendaknya mempertimbangkan cara yang tepat untuk menyampaikan informasi kepada mahasiswa karena terbukti bahwa mahasiswa kurang memperhatikan risiko ketika berbagi pengetahuan secara informal.

\section{b. Pengaruh Knowledge Self-Efficacy terhadap Informal Knowledge Sharing}

Hasil penelitian menunjukkan bahwa Knowledge Self-Efficacy berpengaruh positif dan signifikan terhadap Informal Knowledge Sharing. Pengaruh positif bermakna bahwa semakin tinggi Knowledge Self-Efficacy atau kepercayaan terhadap kemampuan diri pada suatu pengetahuan yang dimiliki mahasiswa maka semakin tinggi pula keinginan mahasiswa untuk berbagi pengetahuan secara informal.

Hasil penelitian mendukung hipotesis kedua dalam penelitian ini. Mahasiswa yang percaya pada kemampuan dirinya terhadap pengetahuan tertentu cenderung akan membagi pengetahuan tersebut secara informal. Hal tersebut sesuai dengan pendapat Endres, et al. (2007) bahwa Self-efficacy dalam kemampuan untuk knowledge sharing dapat memprediksi perilaku knowledge sharing aktual. Knowledge Self-Efficacy mempengaruhi tingkat kepercayaan diri seseorang untuk berbagi dalam suatu bidang tertentu. Orang yang merasa menguasai bidang dalam aktivitas knowledge sharing akan mempunyai kecenderungan untuk lebih aktif. Semakin tinggi Knowledge Self-Efficacy seseorang akan cenderung semakin tinggi aktivitas knowledge sharing yang dilakukan.

Implikasi penelitian ini secara teori adalah seseorang yang memiliki kepercayaan terhadap kemampuannya pada suatu pengetahuan akan mendorong orang tersebut untuk melakukan aktivitas berbagi pengetahuan secara informal. Implikasi praktis dari penelitian ini adalah fakultas hendaknya menyediakan 
berbagai fasilitas pelayanan untuk memotivasi mahasiswa dalam meningkatkan kemampuan diri terhadap bidang ilmunya dan memotivasi mahasiswa untuk selalu membagi dan menerapkan pengetahuannya yang berguna pada masyarakat.

\section{E. PENUTUP}

\section{Kesimpulan}

Berdasarakn hasil penelitian dan pembahasan maka dapat disimpulakan sebagai berikut:

a. Terdapat pengaruh negatif signifikan Sikap Menghindari Risiko Sharing terhadap Informal Knowledge Sharing. Hal ini ditunjukkan dengan koefisien regresi bernilai positif $(0,224)$ dengan nilai $p$ value $0,000(p<0,05)$ dengan nilai koefisien determinasi $\mathrm{r}^{2}$ sebesar 0.092 . Hasil tersebut menunjukkan bahwa $\mathrm{H} 1$ tidak didukung dalam penelitian ini.

b. Terdapat pengaruh positif signifikan Knowledge Self-Efficacy terhadap Informal Knowledge Sharing. Hal ini ditunjukkan dengan koefisien regresi bernilai positif $(0,229)$ dengan nilai $p$ value $0,000(p<0,05)$ dengan nilai koefisien determinasi $\mathrm{r}^{2}$ sebesar 0.103. Hasil tersebut menunjukkan bahwa $\mathrm{H} 2$ didukung dalam penelitian ini.

\section{Saran}

Untuk menghindari kelemahan yang terjadi dalam penelitian ini diharapkan penelitian selanjutnya melakukan perbaikan sebagai berikut:

a. Penelitian selanjutnya diharapkan dapat meningkatkan generalisasi penelitian dengan cara memperluas cakupan sampel sehingga dapat ditarik simpulan dengan generalisasi yang lebih baik.

b. Penelitian selanjutnya diharapkan dapat melakukan triangulasi dalam metodologi penelitan dan teknik pengambilan data. Dengan pengabungan teknik pengambilan data untuk meperoleh data diharapkan dapat menangkap fenomena dengan lebih baik. 


\section{JURNAL NOMINAL / VOLUME II NOMOR II / TAHUN 2013}

\section{Keterbatasan}

Penelitian ini mempunyai beberpa keterbatasan sebagai berikut ini:

a. Penelitian ini hanya menggunakan responden dari 1 fakultas dari 1 universitas sehingga penelitian ini tidak dapat di generalisasi

b. Penelitian ini hanya menggunakan kuesioner untuk menangkap fenomena penelitian yang ada di lapangan. Kuesioner mempunyai karaktristik selfreport yaitu responden diminta untuk menilai diri sendiri tahap ada control yang jelas mengenai pendapat atau jawaban yang diberikan.

\section{F. DAFTAR PUSTAKA}

Alavi, M. dan D. E. Leidner. "Knowledge management and knowledge management systems: Conceptual foundations and research issues," MIS Quarterly, 2001, 25(1): 107-136.

Anita Kristianingsih, "Kemampuan Variabel Akuntansi Dalam Memprediksi Earning Management Perusahaan Manufaktur Di Tiga Negara ASEAN", Thesis Pasca sarjana, Program Pasca Sarjana Universitas Gajahmada, Yogyakarta, 2003

Burgess, D.; "What Motivates Employees To Transfer Knowledge Outside Their Work Unit?” Journal of Business Communication, Vol. 42, No 4, October 2005, pp. 324-348

Burnett, S dan Illingworthz, L., "Anonymous Knowledge sharing in a Virtual Environment: A Preliminary Investigation", Knowledge and Process Management Vol. 15 No.1, 2008, pp 1-11

Cheng, Yeh, dan Tu., "Trust And Knowledge sharing in Green Supply Chains", Supply Chain Management: An International Journal, 2008, 13/4 , 283-295

Cho,Li, dan Su,. "An Empirical Study on the Effect of Individual Factors $\mathrm{n}$ Knowledge sharing By Knowledge Type" Journal of Global Business and Technology, Fall 2007, Volume 3, Number 2.

Endres et al., "Tacit Knowledge sharing, Self-Efficacy Theory, and Application to The Open Source Community" Journal of Knowledge Management, 2007, VOL. 11 NO. 3, pp. 92-103

Erdfelder, E. et al, "GPOWER: A general power analysis program" Behavior Research Methods, Instruments, \& Computers, (Vol.28 No.1), 1996,pp. 1-11

Gefen, et al "Structural Equation Modeling Techniques and Regression: Guidelines For Research Practice" Communications of AIS (Vol. 4, Article 7), 2000 
Gujarati D.N., 1995, Basic Econometrics, McGraw-Hill, Inc., 3rd ed

Hair, J. E., Anderson R. E., Tatham, R. L., Black, W. C., Multivariate Data Analysis With Reading, Prentice-Hall International, 4th Ed., 1995.

Imam Gozali, Aplikasi Analisis Multivariat dengan program SPSS. Semarang: UNDIP, 2009

Kwok, James SH and Gao, S., "Knowledge sharing Community In P2P Network: A Study Of Motivational Perspective", Journal of Knowledge Management, Vol 20, No 1 pp 92-102

Leech, et al., "SPSS for Intermediate Statistics: Use and Intrepertation" Lawrence Erlbaum Associates, Publishers London, 2005

Lelic, S, "Creating a knowledge-sharing culture', Knowledge Management, 2001, Vol. 4 No. 5, pp. 6-9.

Lin, H., "Knowledge sharing and Firm Innovation Capability: an Empirical Study", International Journal of Manpower, Vol. 28, No. 3/4, 2007, pp. 315-332

Lu, Leung and Koch, "Managerial Knowledge sharing: The Role of Individual, Interpersonal, and Organizational Factors" Journal compilation, 2006

Pai, Jung-Chi . "An empirical study of the relationship between knowledge sharing and IS/IT strategic planning (ISSP)", Management Decision, Vol. 44 No. 1, 2006, pp. 105-122

R. Gunawan Sudarmanto, Analisis Regresi Linear Berganda Dengan SPSS, Graha Ilmu, 2004

Riege A., "Three-dozen knowledge-sharing barriers managers must consider", Journal Of Knowledge Management 2005, VOL. 9 NO. 3 , pp. 18-35,

Singgih, Santoso, Buku Latihan SPSS Statistik Parametrik, Elex Media Komputindo, 2000.

Søndergaard S, et. al, "Sharing Knowledge: Contextualising SocioTechnical Thinking And Practice", The Learning Organization Vol. 14 No. 5, 2007 pp. 423-435

Sugiyono.Statistik untuk Penelitian.Bandung: 2007, CV Alfabeta

Tiwana, A., The Knowledge Management Toolkit, Prentice-Hall, Upper Saddle River, NJ. 2002

Wasko, M. M. dan Faraj, S. "The web of knowledge: An investigation of self-organizing communities of practice on the net," unpublished working paper, University of Maryland. 2002

Wasko, M. M. dan Faraj, S., "Why Should I Share? Examining Social Capital and Knowledge Contribution in Electronic Networks of Practice." MIS Quarterly. March 2005 Vol. 29 No. 1. pp. 35-57 